\title{
2012 IOWA REVIEW AWARDS CONTEST WINNERS
}

This issue features the winners of our annual Iowa Review Awards in Poetry, Fiction, and Nonfiction:

POETRY

Emily Hunt, "Figure the Color of the Wave She Watched," "As Long as Relief," "View from a Regular Fantasy," "Another Time Stopped," "Last Night of the Year We Remembered Our Desires" (page 67)

FICTION

Kyle Minor, "Seven Stories about Kenel of Koulèv-Ville" (page 42)

NONFICTION

Bernadette Esposito, “The Principle of the Fragility of Good Things" (page 55)

Congratulations as well to our runners-up, whose work is also featured in this issue:

POETRY: Aditi Machado (page 152)

FICTION: Emily G. Martin (page 74)

NONFICTION: Marcela Sulak (page 162)

Our thanks to everyone who entered, and to our judges: Timothy Donnelly (poetry), Ron Currie, Jr. (fiction), and Meghan Daum (nonfiction).

We also announce Ramon Isao as our Tim McGinnis Award winner of 2012 for the most unusually pleasing and unexpected work of the year ("Rod Stewart Is Everywhere," 42/3). The award is of $\$ 1,000$. 